\title{
DYNASTIC COURTS OF THE HELLENISTIC EMPIRES
}

\author{
Rolf Strootman
}

\section{Introduction}

In the Hellenistic period, royal courts became an important focus of Greek politics. Of course, most peoples and cities in the eastern Mediterranean already were accustomed to dealing with monarchs, both the Achaemenid Great King as well as his various vassal rulers (for instance the Hekatomnid satrap-kings of Karia). However, for the poleis of mainland Greece, the necessity to deal with supranational monarchy did add a new level of "government" to Greek politics, even though the Macedonian kings of the Hellenistic Age rarely interfered directly in the government of cities. ${ }^{1}$ In the remainder of the Near East, the wider political constellation changed in so far that after Alexander the principal ruling dynasties had become Macedonian, and the imperial elites of their kingdoms were predominantly comprised of Greek families who came originally from poleis of both sides of the Aegean - the so-called Friends of the King.

In this chapter, the courts of (mainly) the three major Macedonian dynasties of the Hellenistic period-the Antigonids, Ptolemies and Seleukids-will be examined as instruments of empire and as the loci for the (re)distribution of power, status, and wealth.

A royal court may be defined as consisting of a king's immediate social milieu, the physical surroundings where he lives and where the public ritual of royalty is enacted, and the larger matrix of political and economic relations converging in the dynastic household (Adamson, p. 1999, p. 7). From a social point of view, a court is basically the household of a dynasty complemented by, and entwined with, the households of the

\footnotetext{
${ }^{1}$ See O’Neil (2000), discussing the epigraphic evidence for Hellenistic kings' interventions in Greek civic politics, and concluding that they did so mostly in the capacity of mediators, taking care that their decisions were embedded in civic law; cf. Kosmetatou (1997), showing that the Seleukids despite a strong military presence in Pisidia rarely interfered in the domestic affairs of the towns of that region.
} 
aristocrats belonging to the social circle around the king, for instance military commanders and court functionaries such as the majordomo or chamberlain. A court is not a place, because it can, and often does, move (a notorious case in point is the court of Alexander). The number of people belonging to a particular court is variable; courts expand and contract throughout the year in accordance with the timetable for the aulic "great events" and religious festivals (see also below; for a discussion of these and other characteristics of dynastic courts consult the introduction in Duindam, 2003).

Since Norbert Elias' seminal work Die höfische Gesellschaft (1969)—a study of the French court of the Ancien Régime in the context of the development of absolutism and the rise of the centralized national state-historians have defined the royal court in socio-political terms. However, many of Elias' assumptions have been adjusted or even wholly abandoned in recent scholarship, in particular his essential comprehension of the court as a "gilded cage" for the nobility, an instrument of power manipulated by the monarch (for the present approaches of the royal court see Duindam, 1995 and 2003, and Butz et al., 2004). Early modern absolutism likewise has been revealed to have been more an ideal than a political reality (cf. Henshall, 1992; Burke, 1992b). The same, I would argue, applies to the absolutist pretensions of Hellenistic kingship.

The court culture of the three Macedonian empires developed from the Argead household of Philip and Alexander, absorbing diverse Greek, Iranian and other influences. The courts of the lesser kingdoms of the Hellenistic Age (Pontos, Bithynia, Kommagene, Judea, Armenia, et cetera) in turn underwent the influence of the Macedonian, particularly Seleukid, courts. The Hellenistic courts later also profoundly influenced the development of the Roman imperial court.

Due to intermarriage, competition, the presence of Greeks in the imperial elites, and a shared Greco-Macedonian background, the courts of the three Macedonian empires were strikingly similar. There were also noticeable differences, of course. The Ptolemaic court was firmly based in Alexandria while the Seleukid court moved around the empire almost continually. The Seleukids and notably Ptolemies maintained an elaborate court culture while the Antigonid since Antigonos Gonatas court retained a more simple, "traditional" Macedonian appearance. Royal women played a more profound role at the courts of the Ptolemies and Seleukids than at the Antigonid court. 


\section{Courts and empires}

The Macedonian kingdoms of the Hellenistic Age can be best understood when considered as empires, that is, relentlessly expansive polities based on conquest and composed of a diversity of localized communities, polities and ethnic groups. Especially in the Ancient World, empires normally had a universalistic ideology that did not acknowledge any overlord or rival claimant to power - even if they were no longer successful in their expansionist endeavors (definition after Sinopoli, 1994, p. 159; Pagden, 2001, pp. 7-11; Howe, 2002, pp. 13-5; for the Hellenistic ideology of world empire see Strootman, 2011b). Diversity was their essence. Basically, Hellenistic rulers were leaders of military organizations interested primarily in collecting tribute and gaining access to the resources needed to sustain their military capabilities, and reluctant to become directly involved in the government of subject cities and territories. $^{2}$

Maintaining good relations with cities was of vital importance for the practice of empire. Cities commanded the infrastructure and formed the loci where surpluses were collected, both of which were essential for the exercise of the empires' core business: war-making.

In spite of the old truism that "Chaironeia" terminated the golden age of the independent Greek polis, and the related formula that the slogan "freedom for the Greeks" upheld by Hellenistic kings was a hollow phrase, most cities within the hegemonial spheres of the Seleukid Empire and the Ptolemaic seaborne empire, were not only de iure but also de facto autonomous states. Rather than coerce cities into submission at all cost, Hellenistic rulers preferred to seek peaceful co-operation with urban oligarchies. Consequently, there was much to gain for the cities, too. Rulers could offer protection and bestow on cities various benefactions, trading privileges, exemptions from taxes, and so forth. Thus, cities were allied to kings rather than wholly subjected to them.

Another priority of rulers was securing the allegiance of military leaders, both centrally appointed officials and localized aristocrats, including, as in the case of the Seleukids, vassals and client kings. This required substantial rewards for success, such

\footnotetext{
${ }^{2}$ For the circular interrelationship of civic markets, surplus exaction, and a monarchy's "coercive means" see Tilly, 1990, esp. pp. 1-37.
} 
as land grants, booty, and honors (Sinopoli, 1994, p. 167). This explains why many empires remain focused on conquest and military success (the Antigonid and Seleukid kingdoms are two notable case in point) and why so many empires decline when expansion stagnates.

At this point it should be emphasized that the Hellenistic world was not primarily a Greek world - although contrary to a now popular view, Greek and Hellenized elites did constitute the ruling classes of the Seleukid and Ptolemaic empires at the imperial level (see below); and the "Hellenism" created and propagated at the courts did serve as a cohesive supranational elite culture, also for non-Greek civic oligarchs (Strootman, 2010). Still, many of the cities and elites that especially the Seleukid chancellery had to cooperate with, had a distinct non-Greek identity. The Ptolemies had to do business with the indigenous Egyptian priesthood, whose temples controlled the countryside in Egypt proper together with the Greek and non-Greek landholders protected by the monarchy. The large numbers of Thracian, Illyrian, Paionian and Agrianian troops that were part of the field armies of the later Antigonids suggest that they, too, had more regular dealings with non-Greek military leaders than the Greek (epigraphical) sources suggest.

For all these relations, the court was the focal point. Before a process of "going out of court" began in the seventeenth century CE, that is, the gradual separation of dynastic household and government, royal courts served as the point of contact between the dynasty and the various ruling classes at the local level of the kingdom (Asch, 1991, p. 4; Duindam, 1994, p. 92). The courts of Alexander and the Seleukids on the other hand, while peripatetic, could be "split" if the king went on campaign while his wife (or mother) stayed put in a core region of the kingdom. Negotiations took place especially during the "great events" of the court and the dynasty, such as coronations, birth and marriage festivities, anniversaries, and various religious festivals. Newly created international festivals such as the Ptolemaia of Alexandria, the Seleukid Festival at Daphne, or (to include the Attalids) the Nikephoria at Pergamon, seem to have been expressly created to turn the court into a world-wide social magnet on a regular basis. At such occasions the core of the so-called "inner court" (the king, his family, attendants and closest followers) expanded to include a larger "outer court" of temporary residents. As not even the Ptolemaic court was entirely static-at least as early as the reign of Ptolemy Euergetes the Ptolemies visited Egypt regularly-kings also actively went looking for cities and local elites. The courts of the Argeads, Antigonids and notably the 
Seleukids were by nature peripatetic, following not only seasonal demands and military logic but presumably also civic festival calendars, since it was through personal participation in local and regional cults that the royal presence in a city was structured.

\section{The Hellenistic royal court}

Ancient Greek disposes of a variety of words for "court". Most terminology used in the sources confirms the tendency in present-day scholarship to define a court primarily in socio-political terms.

The fact that a court is in essence a household is reflected in the use of oikos in Greek historiography to denote a Hellenistic royal court. This word connotes the house, property, members and (political and economic) interests of an extended family, and could in the context of monarchy by extension mean "kingdom" (Polyb. 2.37.7). ${ }^{3}$ A more specific term is aule (e.g. Polyb. 4.42.2; Diod. 31.15A.1-3; 1 Macc. 2.46;). Athenaios (189e) explains that this word, which generally signifies the courtyard of a mansion, in the Hellenistic period came to indicate a royal palace "because there are very spacious squares before the house of a king". Archaeology confirms that the structural design of Hellenistic palaces has as its focus one or more open courtyards, and that sometimes there were large squares in front of a palace, for instance at Demetrias, an Antigonid capital, where a Sacred Square (hiera agora) separated the city proper from "royal space".4 The immediate social milieu of Hellenistic kings was therefore frequently designated with the terms "people of the court" (oiJ peri; th;n aujlhvn, e.g. Polyb. 5.26.13; App., Syr. 45; Jos., AJ 12.215) or aulikoi, literally "courtiers" (i.a. Polyb. 16.22.8; Plut., Demetr. 17). Another term often found is therapeia, "retinue". Bickerman

\footnotetext{
3 A more common designation for "kingdom" was ta pragmata, the "affairs" or rather "interests" of the dynasty c.q. the king; basileia meant "[the affairs of] kingship" rather than "kingdom" in any geographical sense.

${ }^{4}$ For an overview of the evidence consult Nielsen, 1994; on Hellenistic palace architecture see further Brands \& Hoepfner, 1996. The hiera agora at Demetrias: Kramolisch, 1989, p. 191. The Romans adopted the word as aula and via this route it reached its present use in modern European languages ("cour", "court", "Hof"), cf. Tamm (1968). The customary word for a Hellenistic royal palace is basileion (Polyb. 10.27.9; Diod. 19.18.1; Plut., Luc. 29.8; Ath. 654b; Jos., AJ 13.136) or the plural basileia, the name of the royal district in Alexandria (Strabo 508 and 524).
} 
(1938, p. 36) maintained that this was the terminus technicus for the (Seleukid) court, but the word is not used this way in official royal correspondence. Moreover, therapeia can indicate both the king's bodyguard (Diod. 33.4a) and his retinue in a wider sense (Polyb. 5.39.1). The term for "courtiers" appearing most often in both historiography and contemporary official documents, is "the friends of the king" - although strictly speaking this was a wider group than courtiers, comprising also relations of the king who were not at court.

\section{The background to Hellenistic court society}

Hellenistic court culture originated in fourth century Macedon. The social composition and organization of the Argead household drastically changed as Macedon expanded and the monarchy became more autocratic. In pre-Hellenistic Macedon, the king still shared power with local barons, the so-called hetairoi, or Companions of the king, a class of land-owning, horse-riding warriors. Although official ideology presented the king as an absolute ruler, he was in practice a primus inter pares among the high nobility. Philip II (359-336 BCE) took the first steps in breaking the dominance of the hetairoi. First he levied infantry among the common Macedonians (the pezhetairoi, Foot Companions), who constituted the phalanx, were directly answerable to the king, and could be used to politically counterbalance the nobility. Second, by attracting to his household men from beyond the hetairoi class. Philip's military successes allowed him to promote his own personal followers and friends whom he recruited not only among the Macedonian nobility but also among Thessalians and other Greeks. Theopompos (FGrH 115 F 225a) expresses how the old nobles must have felt when finding themselves replaced by nonMacedonian favorites at court and in the army: "From the entire Greek and barbarian world men of debauched, villainous and servile character flocked to Macedon and obtained the title Companion of Philip". The upsurge of Greeks, notably Thessalians, at Philip's court moreover was a means to bind Greek states to his person. Occasionally an "outer court" came into existence around Philip and his family, consisting of representatives of Greek poleis and neighboring princedoms and tribes, and even Persian guest-friends. 
Alexander the Great (336-323 BCE) continued his father's policy of bestowing benefices, honors and favors upon his personal friends-partly lesser Macedonian nobles, partly outsiders-and to eliminate his opponents within the aristocracy in cooperation with these favorites. Because of his military successes, Alexander disposed of a vast array of riches and land to distribute among his followers. This allowed him to systematically manipulate the composition of the court and the command structure of the army, and to enforce his decisions without the consent, or even against the wishes, of the high nobility. Anecdotes containing verbal exchanges between Alexander and Parmenion, the principal leader of the aristocratic opposition against Alexander's pursuit of absolutism, bear witness to this process (e.g. Plut., Alex. 29.4). Still, aristocratic opposition to Alexander was not easily overcome (for an overview see Müller, 2003).

Alexander's initial strategy was to advance to prominent positions certain young men who had been royal pages together with him and now were among the seven sōmatophulakes, 'bodyguards', responsible for the king's safety and personal well-being. In defiance of tradition, Alexander promoted his sōmatophulakes to important positions in the army; in 325 he even broke with the traditional number of seven bodyguards by creating an eighth post for the officer of the infantry guard, Peukestas, a favorite whose role it was to support Alexander's introduction of Achaemenid court ceremonial. Thus Alexander was able to gradually remove the leaders of the old nobility and members of the former entourage of his father from senior positions at court and in the army, to be replaced by his protégés. The increasingly harsh conflicts with the Macedonian aristocracy culminated in the execution of Parmenion and his sons in the winter of 330 BCE.

After the final defeat of Darius in 330, Alexander adopted aspects of Achaemenid court culture in order to transform his household into a court more befitting his status as world ruler. He also tried to increase his autocratic power by ritually distancing himself from the growing number of courtiers and commanders surrounding him (see Spawforth, 2007).

Part of this process of transformation was the creation of the chiliarchate, presumably in continuation of the Achaemenid office of the hazarpat (SancisiWeerdenburg, 1980, p. 176). The chiliarch may perhaps be compared with the "GrandMaître de l'Hôtel" of the Ancien Régime (rather than with a modern "prime minister"), that is, a key dignitary responsible for the daily affairs of the royal household who 
helped regulating access to the king's person (Strootman, 2007, p. 152). The introduction of Persian ceremonial also helped bind the Iranian nobility to his person. Outer court of representatives of (Iranian) nobility.

After Gaugamela (331), Alexander in addition promoted Persians to senior positions, most famously Darius III's brother Oxyathres and the former Achaemenid grandee Mazaios. They were allowed to call themselves suggenēs, "relative", of the king, a honorific title also in use at the Achaemenid court, and had the right to greet the king with a kiss. Of course, Alexander initially will not have been able to remove all Iranian nobles from their positions even if he had wanted to, but in this case the king in all probability benefitted from the presence of these powerful outsiders at his court, as indeed the irritated reactions of several Macedonian aristocrats reveal (e.g. Arr., Anab. 7.11.6; Plut., Alex. 43). However, various Achaemenid officials who initially had been left in office were replaced by Macedonians from Alexander's inner circle upon the king's return from the east. For instance Orxines, the satrap of Persis, was accused of maladministration and summarily executed to make place for Peukestas.

\section{The Friends of the King}

Like Philip and Alexander, the Diadochs tried to select their closest collaborators on the basis of loyalty and merit. Lysimachos, Antigonos, Seleukos and Ptolemy benefitted from warfare and conquest, which supplied them with land, wealth and honor to distribute among their followers.

The transition from pre-Hellenistic Macedonian court society tot the Hellenistic court societies was marked by the replacement of "Companion of the King" by "Friend of the King" as the genuine Greek term for someone belonging to a social circle connected with the monarchy. ${ }^{5}$ "Friend" (philos) in the course of time acquired a somewhat more formal gist in some contexts, but up until the end of the Hellenistic period the most powerful Friends remained attached to the royal household by means of informal ties of ritualized friendship known to the Greek s as philia.

\footnotetext{
${ }^{5}$ Modern literature on the various philoi societies is still not very substantial; for general discussions see Herman, 1980/1981 and 1997; Le Bohec, 1985; Weber, 1997; Savalli-Lestrade, 1998; O’Neil, 2003 and 2006; Strootman, 2011a.
} 
Royal philos is a broad term indicating any friendly relationship of the king with private persons, including those not present at court. The philoi of the king were of varied ethnic origin, though they were primarily citizens of Greek poleis (Habicht, 1958; O'Neil, 2003, 2006; Strootman, 2007, pp. 124-134). They were drawn into the orbit of the court from an immense area, coming even from cities beyond the empires. For instance at the court of Antiochos the Great, out of a total of 41 friends whose place of origin has been recorded by Polybios and Livy, more than $50 \%$ came from cities outside the actual Seleukid sphere of influence (Strootman, 2007, p. 126). The Seleukids relied particularly on Greeks from Asia Minor and the Aegean, even after their Anatolian empire had been lost in 188 BCE. This said, it is also noticeable that within the open and cosmopolitan social framework of the Hellenistic courts, a minority of Macedonian nobles continued to dominate the highest stratum of the court societies of the three major dynasties, although their number continually decreased even in the Antigonid kingdom. They are usually not called philos.

Regarding non-Greeks: Alexander left many former Achaemenid grandees in crucial positions following the defeat of Darius in 330, but attempted to replace them after his return from Baktria and India. The indigenous elites reacted to their exclusion from the centre of power by retreating to their provincial power bases in relatively peripheral regions like northern Anatolia, Armenia and the Zagros Range. From there, Iranian principalities such as Pontos, Atropatane and frataraka Parsa gradually emerged, states initially forming part, one way or other, of the Seleukid imperial superstructure. The foundation of this was Seleukos Nikator's good relations with Iranian aristocracies, who helped him pacify conquered territories, gave him access to the manpower resources of the Iranian east, where heavy cavalry was recruited. ${ }^{6}$ Also as the result of constant intermarriage with regional Iranian dynasties the number of Iranians that formed part of the social circles surrounding the royal family must have been substantial. At the Ptolemaic court of the second and first centuries BCE Egyptians turn up as favorites, that is, outsiders promoted to high office to offset the power of the established court society (see below). This said, it remains noticeable that the formal philoi even of the Seleukids and Ptolemies were Greeks or cultivated an Hellenic identity.

\footnotetext{
${ }^{6}$ Iranian loyalty to the Seleukid house remained intact well into the second century BCE: the armies of Antiochos III at the Battle of Magnesia (190 BCE) and Antiochos IV at the Daphne Festival (c. 165 BCE), included thousands of Iranian noble cavalry (Liv. 37.40.1-14 ; Polyb. 30.25.1-11).
} 


\section{The paradox of power}

By sharing power with others, kings inevitably risked losing power to others. This is the recurring dilemma of all despotic, personal forms of rulership: handing out favors and land initially will create a group loyal to the king, but almost as a rule this will eventually burden the ruler with newly-established interest-groups defending their own privileges instead of working in the interest of the king (Duindam, 1994, pp. 50-1).

Kings needed helpers who were both competent and controllable. Ideally, they chose as their closest collaborators men who could not themselves claim positions of importance by right of birth or otherwise, as such men are least difficult to remove from high office and thus more loyal. In other words, kings tend to select their courtiers as much on personal grounds as for their military or other professional capabilities. In practice, however, kings rarely really controlled the social composition of their courts completely. The first generation of Diadochs may have had exceptional opportunities to "hand-pick" their friends, but not even they disposed of absolute power to appoint men of their own choosing to all crucial posts at court and in the army. The loyalty of the philoi therefore always remained a matter of constant concern for kings. The principal danger was not revolt. Rebellion against the legitimate monarch was difficult to conceive and furthermore hazardous, since the armed forces normally were loyal to the dynasty. In the east there are examples of non-dynastic rebels from within trying to replace the (Seleucid) dynasty with their own basileia, most notoriously Molon and Diodotos Tryphon. They failed. Malcontent courtiers could however unite with a dynastically legitimate claimant to the throne or join a rival court, taking their personal satellites, influence and even troops with them. Still, most threatening for kings was the situation in which powerful men remained devoted adherents of the dynasty but acted completely at their own discretion, without the king's consent or even against the king's wishes. This persistent problem will be further discussed later on. 


\section{The royal council}

The upper crunch of the philoi at court had a seat in the royal council, or sunedrion, granting them access to the person of the king on a regular basis, and hence influence on political matters. Especially at the Argead, Antigonid and Seleukid courts, the members of the council were military commanders before anything else. In all accounts of the informal meetings of the royal council at Alexander's court, its members invariably discussed military matters (Hammond, 1989, 143-4). Polybios (4.87.7) the calls counselors of Philip V alternately the king's "courtiers" (peri; th;n aujlhvn), "commanders" (eJgemovnai), and "co-generals" (sustrateuomevnwn).

The council advised monarchs on important matters, especially concerning war and foreign relations. In the Ptolemaic kingdom, the council at various occasions managed the affairs of the monarchy in the name of a minor successor (e.g. Polyb. 4.76.1; Caes., BCiv. 3.105), with sometimes one of the council-members being appointed guardian (epitropos) of the child-king (Poly. 15.25.21; Diod. 30.15.1 2 Macc. 3.7; Caes., BCiv 3.108). Members of the sunedrion were often present when kings received foreign ambassadors. Yet the authority of the royal councils was unofficial and informal. In historiographical sources the sunedrion appears as the single most important body in the Hellenistic kingdoms, but the word is absent from inscriptions. A fundamental aspect of the ideal of equality among the philoi who were present at the council was forthrightness, parrhēsia, an aristocratic ideal and a pivotal virtue in the moral complex of philia (Konstan, 1997, pp. 93-4; Raaflaub 2004). In the context of Hellenistic monarchy this finds expression in the topos of the ruler going towards his doom after ignoring the advice of his friends (e.g. Ptolemy Keraunos in Diod. 22.3.1), and the topos of the king who is corrupted by power and surrounds himself with sycophants never disagreeing with him (e.g. Philip V in Liv. 35.17.3-4). Moreover, in case of disagreement influential persons or factions could sometimes enforce a decision against the king's wishes, so that kings needed to secure support for their plans in advance. To the outside world, however, king and council presented an image of unity. ${ }^{7}$

\footnotetext{
${ }^{7}$ In continuation of former Argead practice, the Hellenistic sunedrion also acted as a tribunal in cases of treason against the king, though not as a formal judicial court: counselors tried their peers because treason was first of all violation of philia and because it was a noble prerogative to be tried by equals.
} 


\section{The Royal Pages}

One interesting group around the ruler, attested for the courts of all Macedonian kingdoms, are the royal pages (basilikoi paides)—an age group consisting of youths between about their fourteenth and eighteenth years and functioning as "a training school for the commanders and officials of the Macedonians" (Curt. 8.6.6). They were the sons of nobles, including the king's own sons. They were educated and trained at court, waited on the king, and guarded him. It was originally and Argead institution, dating back to the late fifth century BCE (Hammond, 1990, pp. 261-4), and continued by the Antigonids, Seleukids and Ptolemies "until the kings from whom the Romans many years later took away all power" (Curt. 8.6.6). There is some evidence that a similar institution for girls existed at the Ptolemaic court. 8

In the Macedonian kingdoms after Alexander basilikoi paides presumably came from leading families of the kingdom's provinces, and/or were the sons of courtiers and foreign xenoi. The king's own children, too, were basilikoi paides during their adolescence. It is not known on what grounds boys were admitted to the pages corps. Neither is it possible to say whether non-Macedonian, non-Greek magnates sent their sons to court, as one would expect especially in the Seleukid Empire.

The king's sons and the other pages received an education under the supervision of a court dignitary usually called tropheus, Foster-Father. The office of tropheus had been a position of great honor already at the court of Philip II (Plut., Alex. 5). Even after their accession to the throne, kings normally held their former tropheus in esteem, addressing him as "father" (Polyb. 31.20.3; Plut., Ant. 5.31; OGIS 148, 256; 1 Macc. 11.1 ; Jos., AJ 12.127; Diod. 33.4.1). Illustrative in this respect is the career of Krateros, a courtier of Antiochos IX, who had been the king's tropheus and was honored by his former pupil with impressive aulic titles: "Foster Father of Antiochos Philopator; First Friend of King Antiochos; Chief Physician and Chamberlain of the Queen" (RIG no. 1158; cf. App., Syr. 68; Jos. AJ 13.271). Men who had been brought up together with the king as

\footnotetext{
${ }^{8}$ Polyb. 15.33.11, mentioning "some young girls who had been (queen) Arsinoe's suvntrofoi; in the Grand Procession of Ptolemy Philadelphos there were 500 paidivskai dressed in purple chitons with gold girdles. (Ath. 200 e). For evidence and literature concerning post-Argead pages in general: Strootman, 2007, p. 181 n. 303.
} 
pages were afterward honored as the king's suntrophoi, Foster-Brothers, and addressed one another as "brother".

Detailed information concerning the pages' duties is provided only for the court of Alexander the Great (see Heckel, 1992, pp. 237-98). The classic text is Curtius 8.6.2-6:

They took turns keeping watch at night at the door of the king's bedchamber, and let in his women through an entrance other than that watched by the armed guards. They also took the king's horses from the grooms and presented them for the king to mount; they accompanied him in the hunt and in battle; and they were educated in all aspects of the liberal arts. They regarded it as a great honor that they were allowed to wait on the king at his table.

The presence of pages at court is an all-time monarchical phenomenon. It was a means to pacify the nobility. Royal pages may have been hostages of sorts, but bringing up the children of powerful men in the royal household, under the custody of the king and cut off from their families, first of all was a means to create a loyal elite and to manipulate noble identity. Indeed, kings often recruited their closest collaborators from the ranks of their former fellow pages, their boyhood friends so to speak.

However the presence of pages may have endangered the domination of the king over his court. If the paides were indeed (in part) the sons of philoi, the pages system was tantamount to the emergence of an hereditary aristocracy at the royal courts, and thus may have gradually undermined the kings' freedom in choosing their friends.

\section{Friendship}

The principal arrangement underlying the relation between king and courtiers was philia, the Greek moral complex of ritualized friendship. Philia may be defined as a personal, reciprocal bond of loyalty and solidarity between two or more individuals of approximately equal status who share roughly the same interests; they were committed to each other by mutual obligations, and could rely on each other for help (Goldhill, 1986, 82; Herman, 1996, p. 116-7). The objective of philia normally was to achieve a common goal, and united action towards that end was a means to strengthen and display the bond (Herman 1996, p. 612; Konstan 1997, p. 97). Philia moreover had traits of 
fictive kinship. In the Iliad it is said that a good friend is "in no way less than a brother" (Il. 8.584-6; cf. Van Wees, 1992, pp. 44-8). This may be associated with Aristotle's dictum that a philos is "one's other self" (Eth.Nic. 1169b 6), which in turn is reminiscent of a famous anecdote, related by Curtius (3.12.17), in which Alexander exclaimed that Hephaistion "is Alexander too". This explains why royal philoi are sometimes honored as the suggeneis ("relatives") or adelphoi ("brothers") of the king (OGIS 148; 259; Polyb. 4.48.5; Plut., Mor. 197a; 1 Macc. 3.32; 2 Macc. 11.12; Liv. 30.42.6). Violation of friendship was considered highly dishonorable, even impious (Belfiore, 2000).

Royal philoi came from a wide range of Greek cities. A partial explanation of this has been offered by Gabriel Herman (1987) who placed Hellenistic court politics in the context of the Greek tradition of xenia (or philoxenia), a form of interactive ritualized personal relationships usually translated as "guest-friendship". Xenia relations constituted supranational elite networks linking men of approximately equal social status but of separate social units (notably poleis), thus uniting the Greek world at its highest level. It was an aristocratic ideal, an archaic legacy, prominent for example in the Odyssey. Through participation in a social sphere outside the city, civic elites distanced themselves from their inferiors at home and linked up with their equals elsewhere. Xenia was believed to be perpetual, passed on in the male line from generation to generation (Herman, 1996, p. 116). By availing themselves of pre-existing xenia networks, Hellenistic kings could connect with Greek elite families and this "account[s] not only for the preponderance of Greeks among the newly recruited Hellenistic court members, but also for the increasing similarities between the three courts" (Herman 1987, p. 208).

Since philoi joining a royal household normally retained links with their hometowns and families through several generations (Savalli-Lestrade, 1996; Muccioli, 2001), xenia-networks connected the royal families indirectly with oligarchic families in the cities. At court, members of governing elites acted as mediators between the kings and their own communities of origin, "deriving substantial benefits from both systems" (Herman, 1996, p. 613; cf. Bringmann, 1993). In cities we therefore find both honorific decrees for kings dedicated by philoi (e.g. OGIS 128, 171, and 255) and decrees in honor of philoi dedicated by the king (e.g. Syll. ${ }^{3}$ 462; Welles 45; OGIS 317).

This web of relations bound the empires together. Kings could influence civic politics through their philoi, whose families in turn derived status from royal favor and 
thus acquired a decisive advantage over other factions in the internal political struggles of the cities. As members of oligarchic families dependent on royal support, philoi represented the interests of the cities at court, and the interests of the court in the cities.

\section{Gift exchange}

The principal instrumentality in creating and maintaining bonds between king and philoi, was the exchange of gifts and favors (charites; cf. Konstan, 1997, p. 4 and 78). Gift exchange furthermore was tantamount to the royal virtue of generosity, directly related to royal euergetism and the public display of wealth known as tryphe. In Idyll 17, the court poet Theokritos praises Ptolemy Philadelphos as a man who is "generous with gifts, as a king befits, generous to cities and loyal friends" (lines 124-5), and Plutarch skeptically remarked that "kings hunt for men by attracting them with gifts and money, and then catch them" (Cleom. 13.5). The most rewarding gift for the king to give was land. The distribution of landed estates, often including buildings, laborers and slaves, provided the philoi with status as well as a steady source of income.

The exchange of gifts is instrumental in creating or affirming social relations, and normally is a highly ritualized process (Burke, 1992a, pp. 69-71). In his seminal essay on the gift, Marcel Mauss (1925) theorized that all gift exchange is subject to three rules: the obligation to give, to receive, and to reciprocate; reciprocity however is not balanced because the person with the highest status is obliged to offer the most valuable gifts or favors. In an anecdote retold by Plutarch (Mor. 127b), a courtier who requested of Alexander dowries for his daughters was offered the astronomical sum of fifty talents; when the courtier replied that ten talents would suffice, the king retorted: "Enough for you to receive, but not enough for me to give". Such unbalanced gift exchange affirmed status hierarchies but also had the practical consequence that the lesser-ranking person remained indebted and dependent because he would never be able to fully reciprocate. Thus, the exchange of gifts created not only horizontal bonds of loyalty but also vertical bonds of dependence to offset the formal egalitarian ideal in philia relations.

Elias (1969) hypothesized that the requirement of status expenditures drained courtiers of their financial resources, to the benefit of the absolutist monarch because it 
made them reliant on royal generosity. In reaction to Elias' thesis, Duindam (1994, pp. 86 and 95) asserted that the king, too, was the prisoner of the spending pattern because the obligation to validate one's status through extravagant expenditures placed a heavier financial burden on the king than on anyone else. Over-consumption on the part of the king could eventually erode the financial foundation of his military power, or even lead to dependence on wealthy philoi, as happened notoriously to Antiochos III at the beginning of his reign (Polyb. 5.50.7). Kings however could forestall this danger by distributing symbolic gifts as a means to publicly allocate favor and establish the receivers' place within the court hierarchy. The value of a gift was not only determined by its exact worth, but also by the fact that through a gift the status of the giver reflected upon the recipient. To be received and rewarded by a king increased one's own social status enormously (Jansen, 1984, p. 58; cf. Allen 2005). Typical monarchical gifts such as golden crowns and purple clothing-and the right to wear them-were visible tokens of such intangible rewards as "protection" or "favor". When Hellenistic kings after banquets allowed their guests to take home the tableware they had drank and eaten from, this provided the recipient in his own social milieu with concrete proof in the form of pièces de conversation to evidence that he had been invited at the royal table, and derive status from that. A royal gift moreover served also as a symbolon, an inheritable material reminder of a xenia bond. It is also important to note in this context, that relations between kings and cities were structured in the same manner as those between kings and individuals, that is, as a horizontal exchange of gifts and honors, bartering for instance divine honors or tribute for the military protection of a city's autonomy.

\section{Court titles}

In the Seleukid and Ptolemaic kingdoms, court hierarchy was regulated and explicated by means of court titles and offices. The distribution of titles was a form of gift exchange, too. Titles were awarded in combination with material gifts, in particular purple clothing, crowns, or horse's trappings, so that the recipient could show his rank to others and derive status from that. Plutarch (Pomp. 36.5) relates how a man who had received the title of philos with the accompanying gifts from Mithradates Eupator, "put 
on the purple robe, leaped upon the horse and rode through the city, crying: 'All this is mine!'”

Although most evidence for court titulature stems from the Ptolemaic empire in the second century, where indeed the most sophisticated titles system seems to have developed, the system of titulature at the Seleukid court was in essence similar, albeit perhaps somewhat less elaborate. The Antigonids in Macedon were contend to stuck to old Macedonian titles predating Alexander, retaining for instance the honorific office of sōmatophulax at the heart of the inner court (Diod. 30.10.2, 11.1).

Because of the disparate nature of the evidence, the meaning of most court titles remains elusive. In the context of the Ptolemaic court Mooren $(1975$, p. 2) distinguishes "honorific titulature" and "real aulic titulature", i.e. titles indicating concrete aulic functions, such as majordomo or chamberlain.

At the Ptolemaic and Seleukid courts, the word philos (in itself a title of honor) was at the basis of the complex of honorific titulature. After $c .200$ we hear of such titles as First Friends (prw`toi fivloi), Honored Friends (timwvmenoi fivloi), and First and Highly Honored Friends (prw` toi kai; prwtimwvmenoi fivloi) at the Ptolemaic court (Walbank 1984, p. 70; Mooren 1975, passim); the first two also turn up in a Seleukid context (Jos., AJ 12.53; 13.13.85; 1 Macc. 11.27; 10.65). How exactly these titles related to each other can only be guessed at. Two other notable titles of honor attested for all Macedonian courts are suggenēs, Kinsman of the King (e.g. Arr., Anab. 7.11.1; 1 Macc. 11.31; 2 Macc. 11.12; OGIS 148, 259; Liv. 30.42.6; Polyb. 4.48.5; Plut., Mor. 197a; Jos., AJ 16.288) and suntrophos, Foster-Brother of the King (Polyb. 5.9.4; 15.33.11; OGIS 247, 1-3; 2 Macc. 11.22). The latter title indicated that one had been a royal page together with the ruling monarch (see below). The title suggenēs may have had a similar connotation but could also be awarded honoris causa.

The category of "real aulic titulature" comprises first of all titles connected with the domestic affairs of the household. At the early Ptolemaic court the principal dignitary was the dioiketes, the majordomo (P.Tebt. 8 = Austin 265); he was aided by a steward, who was responsible for the reception of guests and the progress of symposia and banquets (Jos., AJ 12.2.12). Two more examples of court officials are the chamberlain (Porphyr. FGrH 260 F 20; RIG no. 1158) and captain of the bodyguard (Polyb. 7.16.2; Jos., AJ. 12.17). The chancellery was led by a (chief) secretary known variously as grammateus (Poly. 15.27.7) epi tou grammateus (Polyb. 4.87.8) and 
epistolographos (Polyb. 31.3.16). Military titles such as stratēgos (general), elephantarchos (commander of the war elephants) and nauarchos (admiral) were part of this category, too, because the higher military offices were monopolized by members of the court. The distribution of military commands was a potential instrument of power because this was normally done on an ad hoc, temporal basis.

\section{Proximity to the throne}

Since the king was the central figure within the court society, a courtier's relative status was determined by the principle of proximity to the throne, that is, the degree to which he was able to gain access to the person of the king, or to persons near the king, or to persons near the persons near the king. Gift exchange, court titulature and etiquette were instrumental in determining a courtier's position within the subtle hierarchy of the court.

Like most autocratic monarchs, Hellenistic kings attempted to regulate access to their own persons as an instrument to control the dynamics of court life. Prohibiting that most people could not approach the king directly, accentuated the privilege of those few individuals who did have routine access to the king, for instance the most suntrophoi, royal women, the king's personal servants, his physician, or bodyguards. Such individuals acted as brokers between the king and others. Especially queens and royal concubines played a crucial role in this respect (Strootman, 2007, pp. 141-2).

Behavior, "good manners", distinguished courtiers from non-courtiers and could be a means to maintain social hierarchies within the court society. ${ }^{9}$ Polybios $(22.22 .1-5)$ gives a rare description of an "ideal" Hellenistic courtier, in his portrayal of the Ptolemaic philos Aristonikos:

He was a born soldier and spent most of his time in the company of other such men, and studying military matters. He was also very good in the art of conversation. In addition to that he was by nature benevolent and generous.

\footnotetext{
9 The significance of courtly behavior as an hierarchizing mechanism was recognized by Elias (1969, p. 135), although he wrongly attributed to the king a free rein in manipulating court etiquette to his own discretion (Duindam, 1995, pp. 97-101).
} 
Erudition and esprit were essential qualities in the competition for favor and status (see e.g. Jos., AJ 12.2.12 and 12.4.9). Philip II enjoyed being surrounded by men "who could say funny things" (Ath 435c). The image of the courtier as a flatterer, although topical, testifies to the importance of the art of conversation at the Hellenistic courts, especially during banquets and symposia. The complexity and learnedness of court poetry, with its references to obscure versions of myths and ingenious literary allusions, give some idea of the level of sophistication that was required to take part in table talk at court.

\section{Conflict}

Theoretically, the philoi depended on the king's grace for obtaining and preserving status at court. As Polybios says, kings "measured friendship and enmity by the sole standard of expedience" (Polyb. 2.47.5; cf. Plut., Mor. 183d). In practice the monarch rarely was the sole source of income and prestige for nobles: "The monarch bestowed favors upon parts of the elite to bind them, and subsequently eliminated troublesome opponents in cooperation with those elites. The elite in turn interceded at court for its own clientele" (Duindam, 1994, p. 79).

Philip and Alexander had been relative successful in pacifying the hereditary nobility of old Macedonia. In the course of the third century, however, new land-owning aristocracies with hereditary prerogatives came into existence, and ancestry again became a condition for status at court. The longer the kingdoms existed, the more the families of leading philoi - who were rewarded for their services to the crown with riches, estates and status - acquired independent sources of wealth and status. Powerful philoi maintained retinues of their own (Plut., Cleom. 32.2; Diod. 343.1; Ath. 245a). The size of one's personal following created power and was indicative of power. But being a patron created obligations to act in the interest of one's clients; philoi furthermore acted as mediators in the interest of their cities of origin (cf. Savalli-Lestrade, 1996), or at least of the oligarchic factions to which they belonged. Thus, various, often opposite interests were represented at court.

Rivalry among the philoi was not the only cause of discord. Because Macedonian kings were polygamous, succession strife was a recurring source of conflict at the 
Hellenistic courts, as was argued by Ogden (1999) who maintained that the "amphimetric disputes" resulting from the supposed failure of the kings to formally hierarchize the royal wives and their sons caused the decline and fall of the Macedonian dynasties (p. ix). However, kings had at their disposal various informal means to overcome the problem of unhierarchized offspring, including the installation of a favorite son as basileus during the father's lifetime and the Ptolemaic practice of brother-sister marriage. It furthermore is difficult to ascertain whether succession strife sometimes was not due rather to a deliberate policy on the part of the ruling monarch to keep the court household divided.

To secure their positions and overcome their rivals, philoi joined forces in factions around powerful men or women-queens, princes, leading men from the sunedrion. Faction leaders in turn tried to gather around themselves a following as large as possible, both as a source of power and as a tangible sign of their importance at court (see for instance Polyb. 15.25.31-4). Thus, conflicts between courtiers could become interlinked with rivalry for the throne. Through involvement in the struggles between wives and half-brothers, philoi could win a lightning career if the prince they supported succeeded to the throne, but risked exile or death when this was not the case. The career of the philosopher Demetrios of Phaleron, former leader of Athens and trusted counselor of Ptolemy I, ended abruptly when he supported the wrong candidate for the succession after Ptolemy's death (Diog. Laert. 5.77-8).

Kings tried, for better or worse, to benefit from these rivalries through the principle of divide and rule. Often, however, kings did not succeed in remaining lofty arbiters but became themselves participants in factional conflict. This happened when Philip V succeeded to the Antigonid throne in 218 BCE (Polyb. 5.25-29) and when Antiochos III became Seleukid king in 223 (on these events see Herman, 1997; Strootman, 2011a).

\section{The promotion of favorites}

To deal with the growing power of the established philoi class, Ptolemaic and Seleukid kings from c. 200 increasingly resorted to the promotion of "favorites". Promoting favorites is an all-time principle of monarchical rule. The ideal favorite was elevated by 
the ruler to a position of power to which he had no title through noble descent or acquired social status, and that he could never have obtained without the king's grace, so that he was entirely reliant on the king for the preservation of his status. Preferably, a favorite would have no children to whom he could transmit his power, at least not officially (Burke, 1992a, p. 48). By making such individuals their closest advisors kings tried to bypass the sunedrion and screen themselves off from the philoi. The favorite would take responsibility for unpopular measures, or take the blame when things went wrong-hence the generally negative reputation of favorites, who are typically stereotyped as the archetypal wicked advisor controlling the king (a good example of this is the description of Herakleides, the Greek favorite of Philip V, in Diod. 28.2; cf. Polyb. 13.4).

Hellenistic kings employed various types of favorites: exiles, defectors from rival courts, foreigners, eunuchs and (last but not least) women. The most exemplary instance of an exile is Hannibal, who sought refuge at the Seleukid court in 196 BCE and became a senior advisor of Antiochos III during the king's war with Rome (191-188); he is described as an anomaly within the sunedrion, constantly disagreeing with the other philoi, hated by them, but enjoying the full confidence of the king who deliberated with him behind closed doors (Liv. 34 infra; Diod. 29.3). The career of Demetrios of Pharos at the court of Philip V provides another example. Exiles were not per definition outcasts: violation of the rules of philoxenia by a king could induce a philos to voluntary go over to a rival court, accompanied by his own followers (see e.g. Polyb. 5.70.10; cf. Strootman, 2011a). A second type of favorite was the social outsider. At the Seleukid and Ptolemaic courts of the late Hellenistic period eunuchs and non-Hellenes were employed as favorites. An Egyptian eunuch named Aristonikos (the ideal courtier we encountered earlier in this chapter) became the foremost philos of an unknown Ptolemy in the second century BCE (Polyb. 22.22.1-5). From 169 to 164, Ptolemy VI patronized an Egyptian called Petosarapis, who was also known by the Greek name of Dionysios. Diodoros (31.15.1-4) claims that Petosarapis wielded greater influence at court than anyone else; he also characteristically accuses him of trying to win control of the kingdom. Among the Seleukids, Demetrios II relied heavily on a general called Dionysios the Mede (Diod. 33.28.1), perhaps a eunuch, and both Antiochos VII and Antiochos IX favored a eunuch called Krateros (RIG no. 1158). 
But the ideal favorites in the Hellenistic kingdoms were neither foreigners nor eunuchs, but women. Queens held an ambiguous position in the Macedonian dynasties. On the one hand they were outsiders in the male spheres of government and army. On the other hand they were central figures in the royal families and households. Because of polygamous marriage the mother of the heir apparent could be expected to be a loyal ally of the reigning king, and to regard the interests of her husband's family as her own. A queen presumably was promoted to this cardinal position by conferring on her a diadem and the title of basilissa (on this title see Carney, 1991) The role of queens was not confined to traditional female responsibilities like public and private cult or the internal management of the household. As temporary regents they necessarily took over the male duties of their husbands or sons, transgressing the traditional borders between the feminine and the masculine. For instance when Antiochos III was campaigning in the Aegean, having his eldest son with him, his principal consort Laodike represented him as monarch elsewhere, maintaining diplomatic contacts with the cities of Asia Minor on his behalf and having authority over the royal treasury (Austin, 1981, no. 156; SEG 26, 1226).

\section{Summary}

At the Hellenistic courts, philoi functioned as intermediaries between monarchy and city. The court society constituted the locus of a complex and far-reaching network of patronage relations. The tentacles of this network "reached into every section of the kingdom, so that the king's power was manifested to his subjects through the members of his court" (Herman, 1997, p. 200). The system, however, worked also the other way round, permitting cities and elite families to exert influence at court. Moreover, royal courts were not the only source of political power in the Hellenistic world. As long as the king was successful and wealthy, he could bind powerful men to and control with their help cities and territories. But when a monarchy impoverished or lost charisma - usually the result of military failure - regional leaders turn easily away to join a rival court or become political rivals themselves.

The court was instrumental in creating cohesion by integrating the dispersed elites of the kingdoms. Through the court, the monarchy gained access to financial 
capital and military resources. Reversely, the philoi who had risen to power in their hometowns precisely because they were the friends of the king (and were dependent on monarchical favor for the continuation of their elevated positions) were not only agents of empire but could also exert influence at court for the benefit of their cities. Their dependence on the imperial system disconnected them from their less lucky peers at home but connected them with royalist aristocrats in other cities so that an empire-wide elite commonwealth came into being together with a sense of being connected with the empire as well as with one's city. Thus the court not merely used pre-existing supranational elite networks, but actively promoted the establishment and growth of such networks. 